\title{
FRANCISCO DE ASSIS BARBOSA, O REPÓRTER QUE SONHAVA
}

\author{
Antonio Arnoni PRADO \\ Universidade Estadual de Campinas \\ arnoni.prado@gmail.com
}

Resumo: O ensaio procura demonstrar a trajetória jornalística de Francisco Assis Barbosa, incluindo no percurso as suas relações com a literatura, a crítica e a história literária, precedidas nos anos de juventude por uma incursão isolada pelo terrenos da ficção.

Palavras-chave: Modernismo. Jornalismo. Crítica. Historiografia literária.

Abstract: The essay surveys Francisco Assis Barbosa's journalistic trajectory, including his relationship with literature, criticism and literary history, preceded in his youth by an isolated incursion into fiction.

Key words: Modernism. Journalism. Literary criticism. Literary history.

A admiração de Francisco de Assis Barbosa (1914-1991) pela obra e personalidade de António de Alcântara Machado (1901-1935) remonta aos anos de juventude, quando, ainda estudante na Faculdade de Direito do Rio de Janeiro, em 1933, ele se apresenta como voluntário para a defesa da causa constitucionalista junto à Bancada Paulista por São Paulo Unido, então empenhada nos trabalhos da Assembleia Nacional Constituinte, reunida na capital federal.

Chico e os quatro rapazes que o acompanhavam foram recebidos pelo próprio Alcântara Machado, que presidia a Bancada. Como recordará mais tarde, aquele foi um momento de grande emoção, particularmente porque - mais que adesão política de voluntário, a cuja causa "não era muito afeiçoado", - o que de fato o movia naquela decisão de moço era no fundo a oportunidade de conhecer pessoalmente o jovem criador do "Gaetaninho", que ele aprendera a admirar, ainda adolescente, na sua querida Guaratinguetá.

$\mathrm{O}$ encontro seria decisivo para a vida intelectual do futuro escritor, pois foi justamente através de Alcântara Machado que Chico se convenceu de sua vocação literária, a ponto de tornar-se um dos grandes estudiosos da obra de Alcântara. Este, por essa época exercendo no Rio atividades políticas que o acabariam elegendo deputado

\begin{tabular}{|l|l|l|l|l|}
\hline Pensares em Revista & São Gonçalo, RJ & n. 1 & $92-116$ & jul.-dez. 2012 \\
\hline
\end{tabular}


federal, dirigia então, a convite de Assis Chateaubriand (1892-1968), o jornal Diário da Noite, para o qual criara recentemente a seção "Literatura \& Cia", muito apreciada pelos leitores. Pois foi nessa coluna que se deu a "conversão literária" de Francisco de Assis Barbosa, mais precisamente, num concurso nela promovido para eleger "o príncipe dos escritores brasileiros", em substituição a Coelho Neto, recentemente falecido. Chico, se lembra, quase comovido, do incentivo que recebeu de Alcântara Machado para inscrever-se no certame.

O episódio, que lhe valeu como estímulo, veio mostrar que ele não se enganara em relação às expectativas literárias implícitas na convivência, mesmo que temporária, com um dos grandes modernistas de São Paulo. Durante o tempo em que permaneceu colaborando com a Bancada Paulista, em geral à noite, após o expediente, não era raro que Alcântara Machado fosse visitado por alguns "monstros sagrados do modernismo", que Chico pôde ver de perto em animada palestra com o narrador de Pathé-Baby (1926), gente como Manuel Bandeira (1886-1968), Sérgio Buarque de Holanda (19021982), Augusto Frederico Schmidt (1906-1965), Dante Milano (1899-1991) e tantos outros. Conversas, é bem verdade, de que não participava como seria o seu desejo, dado que Alcântara era um tipo "fechadão" e pouco disposto à expansão de sentimentos com quem não fosse da sua intimidade.

Hoje, a tantos anos de distância daquele primeiro contato, é possível recompor, na trajetória de Chico, a intensidade com que ele se valeu da aura de Alcântara Machado para ensaiar a sua própria identidade, na tentativa de fazer vingar os estímulos daquela "conversão" que desde então o destinava às letras.

Um de seus primeiros escritos sobre o contista da Pauliceia, derivado daqueles encontros, é um pequeno esboço que apareceu no ano seguinte, justamente na Revista Oficial dos Estudantes da Faculdade de Direito da Universidade do Rio de Janeiro. Nele, desde logo fica claro o seu grau de adesão à prosa de Alcântara, para Chico o principal prosador do movimento modernista. Não que o sobrepusesse a um Mário de Andrade (1893-1945), por exemplo: a este, creditava - na linha de frente da ação de vanguarda - a projeção estratégica dos novos rumos da estética moderna. Alcântara Machado, menos abstrato, segundo ele, "agia direto e construía definitivamente, criando um estilo num sentido artístico".

\begin{tabular}{|l|l|l|l|l|}
\hline Pensares em Revista & São Gonçalo, RJ & n. 1 & $92-116$ & jul.-dez. 2012 \\
\hline
\end{tabular}


Sobre esse estilo, o jovem Assis Barbosa chega inclusive a tecer algumas impressões críticas, identificando, na prosa de Alcântara, a realidade inegável de um "escritor imediato", de estilo "enxuto, sem superfluidades". Este o fator que dava à sua prosa - nos diz ele - "o encanto [de um] fogo vivo que se oculta nos montões cor de ouro das cascas de arroz postas ao sol”. E adiante: "a sua técnica de prosador é importante não só pelo estilo como também pela introdução de um elemento diferente, o intaliano (sic), "novo mameluco", que veio para ocupar o lugar "da surrada exploração do português e do mulato".

Um dos efeitos dessa novidade é, a seu ver, a ausência da paisagem, que Chico estende para "toda a nossa literatura citadina", sem no entanto se deter nas razões desse argumento. A observação, que pode parecer destituída de interesse, ganha importância exatamente porque, sem que o notasse, o alvo crítico de seu breve ensaio vai gradualmente se descolando das observações propriamente literárias para de algum modo enveredar pela originalidade histórica da obra de Alcântara Machado. É claro que não se definem aí as opções intelectuais do futuro historiador, biógrafo, jornalista, repórter de bastidores e cronista exemplar da nossa vida literária. Mas seria um erro deixar de registrar os indícios de algumas preferências que revelam, no espírito de Assis Barbosa, um interesse menos por elucidar a fisionomia literária de Alcântara Machado, do que por registrar a lucidez do historiador que ele foi.

Basta notar que, ao endossar a opinião de Afrânio Peixoto (1876-1947) no "Prefácio" às cartas de José de Anchieta - onde o autor de Bugrinha (1922) revela o fascínio pela "sedutora personalidade do ladino padre jesuíta [...] como artista e como homem de inteligência jogado na brutalidade da colônia”, - ao endossar essa opinião, Chico não apenas se vale da imagem incontroversa desse abandono, como decide mergulhar, ele próprio, no destino incerto da missão arriscada do padre, ao "imaginar Anchieta (só pelo prazer de imaginar) nos vagares de sua vida atormentada entre uma confissão e um parto (já que até de parteiro ele serviu), transportando-se em pensamento para uma das casas europeias da Companhia, de douto convívio e excelente biblioteca, e depois afagando o seu amor às letras no desvelo pelos brasis". Ou seja, é como se Chico, fascinado pelo tema pesquisado por Alcântara, entrasse na própria cena do abandono virtuoso a que se devotou Anchieta e partilhasse, ele mesmo, daquela vida desgarrada e cheia de incertezas.

\begin{tabular}{|l|l|l|l|l|}
\hline Pensares em Revista & São Gonçalo, RJ & n. 1 & $92-116$ & jul.-dez. 2012 \\
\hline
\end{tabular}


É verdade que, louvado em Rodrigo Melo Franco de Andrade (1898-1969), nos dirá mais tarde que os textos do Alcântara Machado jornalista e comentarista politico, diferentemente do que ocorria com a sua prosa literária, não possuíam grande valor; mas ainda assim - assinala - eles se mostraram de extrema importância no combate "à funesta propagação do micróbio do integralismo", com o que destacava a dimensão política da literatura, que - como veremos adiante - será uma das marcas mais visíveis de seu ideário crítico.

Mas não é tudo. Lembremos que um ano antes, certamente encorajado por aquele “incentivo" de Alcântara Machado, Chico publicara a novela Brasileiro tipo 7 (1934), repleta de tiradas modernistas, a começar pelo "Discurso inicial", uma espécie de introdução sarcástica à Mário de Andrade, em que ele diz ao leitor que pouco lhe interessava se o livro estivesse bem ou mal escrito: o mais importante era que e o leitor "não o levasse a sério".

Tentava, com isso, bem se vê, inserir-se na linhagem gaiata que os modernistas inauguraram, como aliás nos mostram outras passagens do livro, - uma biografia falhada de um tal José Maria Boaventura de Jesus, tipo entre o bizarro e o convencional, cuja história incorpora os cortes temporais abruptos à Oswald e Alcântara Machado, acelerando o detalhe do motivo livre para convertê-lo em fator essencial do relato, como na cena do xingamento ao professor Tonico, que um aluno, no pátio, começava a escandir para os colegas:

Filho da pu... Não acabou que o tapa achatou o nariz, fechou a boca do coitado.

"Seo" Tonico passava na horinha ali perto.

O resto do curso foi tão sereno... mas cheio de triunfos.

Formou-se com distinção. Tinha vinte e um anos. Só.

Isto para não falar nas interferências do narrador, que palpita livremente na articulação do enredo e chega mesmo a entrar em cena, ao menos uma vez.

Eu entrei no primeiro capítulo deste livro numa bruta calma. Não quis imitar Gastão Cruls, que pediu licença, meio tímido, tomando parte num bom romance que fez, com medo de desgostar os leitores /.../ porque um sujeito francês também tinha feito a mesma coisa... Eu não.

\begin{tabular}{|l|l|l|l|l|}
\hline Pensares em Revista & São Gonçalo, RJ & n. 1 & $92-116$ & jul.-dez. 2012 \\
\hline
\end{tabular}


Não tenho que dar satisfações aos meus leitores. Desculpem a franqueza. Entro de novo com a maior sem-cerimônia.

E não foi vaidade que me trouxe. Venho desfazer uma complicação.

Sou um sujeito que comecei e perdi o fio da história.

E o narrador, que reaparece à página 93 unicamente para fazer blague,

- Me conhece?

- Não seja besta. Então não se lembra?

Olhou-me. Olhou bem, pra falar de novo:

- Ou muito me engano ou você é o Chico Barbosa.

- Seu amigão, velho coisa ruim...,

insiste em desqualificar o seu próprio texto, com ironia e farto comichão modernista:

Tens razão, amigo Bilac...

Que comecinho besta de crônica! Onde já se viu? Rasguei o papel linha d'água.

Enforquei o queixo nas mãos. Boaventura dançou na minha cabeça. Não me largava mais aquela cara pregada no meu pensamento.

Mas a blague e a irreverência, que então moviam a estratégia de um narrador encantado com a arte de Alcântara Machado, não vão além dessa primeira tentativa ficcional. Ou porque recuasse ante a pouca repercussão da novela, ou porque acabasse se convencendo de que o seu modo de exprimir a vida e os sentimentos do mundo viesse mais da constatação do vivido e menos da figuração dos sonhos, o fato é que preferiu relatar a vida a partir das singularidades e do histórico dos homens enquanto expressões da experiência concreta na faina do dia a dia. Repórter mais que literato, jornalista ao encalço dos sonhos e verdades que transformam as coisas, o que vai despontar com o Chico Barbosa dos anos de 1940 é sobretudo o cronista da história e da cultura, o anotador do presente carregado das impressões do passado, que se colam a cada passo à moldura dos textos que vão sendo escritos.

Para quem lê as entrevistas que publicou pela revista Diretrizes, a partir dos anos de 1940, por exemplo, essa impressão é inevitável. Em "Nair de Tefé : sou francamente pelo sorriso em matéria de caricaturas", reportagem estampada pela revista em 7 de maio de 1942, temos uma espécie de modelo dos relatos que ele então produzia para a

\begin{tabular}{|l|l|l|l|l|}
\hline Pensares em Revista & São Gonçalo, RJ & n. 1 & $92-116$ & jul.-dez. 2012 \\
\hline
\end{tabular}


imprensa. Na paleta do jornalista que visitava a célebre caricaturista, são inegáveis os enquadramentos literários de que se vale para relatar a conversa.

Num primeiro momento pela delimitação do foco, visível no modo como o repórter descreve o espaço, alinha as notações de tempo e circunstâncias, para só então apresentar a personagem principal e, depois, as secundárias, caso específico de Rebeca, a simpática negra que o recebeu à porta do Vilino Nair, em Petrópolis. É nessa espécie de preâmbulo, que Chico informa ao leitor os aspectos mais importantes que cercam o cotidiano e o ofício da entrevistada, sua formação e habilidades, bem como as referências inéditas sobre a sua personalidade e o mundo de suas relações, tudo enfeixado em notas biobibliográficas e históricas acerca do papel de Nair de Tefé na cultura, na política e na sociedade de seu tempo.

É assim que, naquele domingo chuvoso de 1942 em que Chico bate palmas à porta do Vilino Nair, tendo a atendê-lo "uma vistosa negra sorridente, com um grande gorro na cabeça - "Dona Nair saoiou, ela foi no cinema. Senhorr vem cá quatro horra-s. Pode vir? Bom" - vamos aos poucos ingressando num segundo momento da estratégia do repórter, que interioriza o foco com olhos para todos os pormenores que o transformam num autêntico narrador onisciente, quando, à tarde, ele retorna para começar a entrevista.

Passam então diante dos nossos olhos desde os detalhes da recepção que recebeu de Nair de Tefé até os informes sobre as origens de dona Rebeca, a criada (nascida nas Bermudas), passando pela descrição da sala de visitas com um "retrato a óleo de uma jovem de olhos azuis, boca miudinha, rosto de pêssego, corado e risonho". É Nair de Tefé "aos vinte anos em flor". “Oh, a mocidade de Nair!" - é o repórter expandindo as asas da imaginação para retornar no tempo: "Quanta coisa a recordar! As grandes festas do Rio do começo do século, as elegantes temporadas do verão em Petrópolis, o Teatro Municipal com a Réjane ou com a Ianka Chaplinska, as caricaturas de Rian, o casamento com o Marechal”.

Esse modo de ingressar nas cenas de seus próprios relatos, como vimos atrás, tem para Chico um apelo literário específico, o de reviver a plenitude do sonho ficcional de origem, quando ainda sonhava em fazer literatura. Desviado para o jornalismo, que aliás exerceu com a maior competência, levou para os seus textos de imprensa uma espécie de nota inventiva que revestia de um toque lírico a notação concreta de tudo que

\begin{tabular}{|l|l|l|l|l|}
\hline Pensares em Revista & São Gonçalo, RJ & n. 1 & $92-116$ & jul.-dez. 2012 \\
\hline
\end{tabular}


informasse ou descrevesse. É ela que infunde ao repórter, por exemplo, a sensação de que "o Vilino Nair é hoje uma casa melancólica", palco de reminiscências distantes onde Nair "viveu alegremente toda a juventude", como que "escondida do mundo" e cercada dos entes queridos que ali faleceram.

Mas, a partir dos informes sobre a formação de Nair de Tefé na Europa, a dicção literária perde força e o repórter vem para a boca de cena. É quando vemos Tefé primeiro menina, no convento de Santa Úrsula, na França, a rabiscar sua primeira caricatura em cima do "nariz muito comprido" de uma das professoras, que a conduziu irritada para a madre superiora: "Mlle. de Tefé, vous êtes une petite péronnelle". E depois no curso particular de Mlle. Anne Vivaudy, de onde se transferiu para Paris, a estudar piano com Mlle. Louise Lavrut, que lutou como pôde para desviá-la da caricatura.

Nada, porém, impediria que Nair se transformasse num "dos nomes mais interessantes da caricatura universal", segundo informa o crítico cubano Bernard G. Barrios, conforme os dados que o aplicado repórter colheu no capítulo de La caricatura contemporánea (1916), de onde extraiu inclusive um trecho expressivo em que Tefé aparece como "a primeira caricaturista do mundo e uma das mais notáveis representantes do humorismo sul-americano".

O que segue depois disso é a rica profusão de dados concretos que só as boas reportagens conseguem trazer ao leitor: Tefé de volta a Petrópolis, para a casa que tanto amava; o início da prodigiosa carreira a partir de 1906-1907; os incentivos decisivos de Laurinda Santos Lobo; a colaboração expressiva em revistas como Careta, Fon-Fon, além do jornal Gazeta de Notícias, a que se juntam as investigações pessoais do repórter Assis Barbosa, que nos confessa haver estado na Biblioteca Nacional em busca do livro Petrópolis encantada, de Heitor dos Prazeres, levado pela atração que sentiu pela "vasta galeria de caricaturas" que viu pregadas nas paredes do Vilino, com o registro de grande segmento da vida elegante do Rio de Janeiro de 1910, mostrando diplomatas, políticos, escritores, poetas, artistas e gente da alta sociedade.

Isto sem falar nas primeiras exposições de Nair, autorizadas pelo pai, seja no cavalete da Casa David ou no da Chapelaria Watson, onde a carreira de Tefé deslanchou, a ponto de suas charges começarem a circular em jornais de Paris, o Excelsior à frente, mas também nas revistas Femina e Le Rire. Já casada com o

\begin{tabular}{|l|l|l|l|l|}
\hline Pensares em Revista & São Gonçalo, RJ & n. 1 & $92-116$ & jul.-dez. 2012 \\
\hline
\end{tabular}


marechal Hermes da Fonseca, ela poderá viver pessoalmente o êxito que obteve na Europa, seguindo para a França e a Suíça depois que o marido deixou o poder.

Mas os cuidados do repórter vão ainda mais longe, ao trazer ao leitor os depoimentos de Tefé sobre a sua própria obra. Admiradora de Losques e de Julien, grandes caricaturistas daquela época, ela define, a pedido de Chico, a linha de suas charges, ao confessar que nunca foi adepta "da deformação total do caricaturado".

"Sou o contrário de um Rouveyre, por exemplo". E acrescenta: "este transformava as pessoas quase que em macacos. Eu sou diferente. Os meus bonecos não provocam gargalhadas, despertam sorrisos. Sou francamente pelo sorriso, em matéria de caricatura".

Com a morte da mãe em 1934, Nair de Tefé deixou definitivamente a caricatura.

Chico encerra a entrevista com as providências de praxe, para um repórter dobrado de ficcionista. Como as cortinas de uma cena que se fecha, as despedidas se completam feito impressão que se desfaz, engolida pela cerração de Petrópolis.

A verdade, no entanto, é que, ao deixar o Vilino Nair, Francisco de Assis Barbosa já voltava para o Rio com um modelo próprio de fazer jornalismo, entremeando em seus textos a argúcia documental de repórter e o enlevo do narrador literário, de que nunca se afastará, como o atestam os trabalhos que nos deixou no terreno da biografia, da editoração e da própria historiografia literária.

Num livro que dividiu com Joel Silveira nesse mesmo ano de 1942 não são poucos os indícios do que acabamos de afirmar, a começar pela natureza dos temas e da vocação intelectual dos entrevistados com quem conversa na primeira parte do livro.

O leitor atento se surpreenderá com a variação de registros com que Chico Barbosa reveste o seu modo de compor e estruturar os relatos. Assim é que na entrevista com Villa-Lobos, por exemplo, - um bate-papo de uma hora e meia entrecortado de interrupções e boas gargalhadas -, o narrador não perde um detalhe dos movimentos de seu entrevistado, como na melhor tradição do registro testemunhal. Diante de Villa, é como se Chico disparasse a câmera para não perder um único gesto da fisionomia que se transformava permanentemente à sua frente. "O homem é um turbilhão. Quando fala, é uma torrente" - nos diz ele - redesenhando os gestos do maestro que gesticula, sacode as mandíbulas, os cabelos dançando, as palavras explodindo, “duras, ásperas, sinceras. Bonitas, às vezes como bolas coloridas".

\begin{tabular}{|l|l|l|l|l|}
\hline Pensares em Revista & São Gonçalo, RJ & n. 1 & 92-116 & jul.-dez. 2012 \\
\hline
\end{tabular}


O primeiro efeito é a surpresa das confissões bombásticas, como convém ao trabalho de um bom repórter. À vontade diante de um interlocutor atento, Villa-Lobos não mede as palavras: "costumo falar sem rebuços, fira a quem ferir", e os petardos zunem para todos os lados. Primeiro em direção aos seus críticos ("primeiro chamaramme de inculto, depois de louco, depois de futurista, depois de tudo que termina em ista, menos de artista") e em seguida em cima dos medalhões de seu tempo. Um bom exemplo: "pretenderam transformar o Graça Aranha no maior pensador brasileiro. Protestei. Não é assim, não. Tinha talento sim, de sobra. Mas que vale o Graça diante de um Eça de Queirós?”. Ou ainda: “Toscanini é da música de casaca, com luneta e polainas. É um requintado. Não quer saber de renovar-se. Tem medo de sujar os dedos. Para quem faz da arte a própria vida, Toscanini representa zero vezes zero”.

Aqui, como o leitor terá notado, ao mesmo tempo que a argúcia do repórter fisga no entrevistado a imagem demolidora de um tipo desconcertante, como era de fato Villa-Lobos, o arranjo escrito do texto acompanha, ao nível das palavras e das frases, a impressão desagregadora do entrevistado, feito estratégia para construir personagens.

Não é à toa que a própria relação entre o escritor e o ofício literário ocupará o centro da entrevista de Chico com o poeta Augusto Frederico Schmidt. Nela, o repórter se interessa justamente por elucidar o peso da vocação literária tanto na vida profissional de Schmidt, quanto em face do mundo então ameaçado pelos horrores da guerra. Mas no fundo o que buscava era um desmentido: Chico não se conformava com o pessimismo do autor de Mar desconhecido, que, numa reportagem de 1936, pressentira o "fim da poesia" ante a barbárie que acossava a humanidade.

"Aquela entrevista, eu dei num instante de abatimento" - dirá o poeta, ao confessar-se então desalentado com "a falta de influência da poesia no mundo moderno". Mas, enfático, garante ao repórter: "não anunciei jamais a morte da poesia. Isso é um absurdo. Só os que não sabem ler é que tomaram aquela minha entrevista como um atestado de óbito que eu estava passando à poesia".

Esse interesse de Chico pelo vigor do talento, do método de criação e da personalidade intelectual dos escritores ficará como uma espécie de leitmotiv dos escritos com que depois incursionará pela crítica e a vida literária. Um bom exemplo é o de sua entrevista com José Lins do Rego, quando pede ao romancista que nos revele as fontes de onde partia a sua inspiração. Ao longo da conversa, que torce o seu rumo

\begin{tabular}{|l|l|l|l|l|}
\hline Pensares em Revista & São Gonçalo, RJ & n. 1 & $92-116$ & jul.-dez. 2012 \\
\hline
\end{tabular}


como que indefinida entre as reminiscências da infância e os ecos perdidos da mocidade, Chico arranca de Zé Lins a imagem da velha Totonha, ao fluir de cujas histórias o então menino de engenho se impressionou com os relatos de Troncoso, que lhe serviram de "iniciação literária", ao lado de três maiores influências: Olívio Montenegro, José Américo de Almeida e Gilberto Freyre. A de Montenegro, pela iniciação em literatura francesa; a de José Américo, pela liderança intelectual exercida sobre os moços da Paraíba e, particularmente, por haver corrigido o único soneto que escrevera em sua vida"; e a de Gilberto Freyre, pela orientação constante que começou no mesmo dia em que se eles conheceram, numa tarde de 1925. "Para mim - escreveria o romancista no prefácio de Região e tradição - tivera começo naquela tarde de nosso encontro a minha existência literária". É então que encontra o seu rumo, larga o curso jurídico e põe tudo de lado para deixar-se ficar "lendo furiosamente na biblioteca da faculdade", não apenas os escritos de Freyre, mas as suas indicações literárias, sociológicas e culturais de um modo geral.

O mesmo tema reaparecerá com mais força quando, em 6 de janeiro de 1944, Chico publica na revista Diretrizes, do Rio de Janeiro, a entrevista (última concedida pelo poeta) em que Mário de Andrade reafirma a sua posição "como artista e como homem", desvelando as duas faces que, na expressão do repórter, se soldavam "numa só pessoa verdadeira, na constância admirável de toda uma existência dedicada inteiramente ao trabalho intelectual”.

A novidade, aqui, vem de que o repórter faz coro aos desabafos de Mário, de quem partilha as ironias e o pessimismo, a ponto de por vezes converter-se numa espécie de arauto do poeta. Há momentos, mesmo, em que, referindo-se aos desafogos do autor do Macunaíma, Chico previne o leitor de que "as palavras de Mário são duras, vão doer em muita gente". Mas adverte: "Paciência. São palavras que precisavam ser ouvidas", sobretudo por serem ditas num tempo de barbárie e de atrocidades.

"É bem uma definição de atitude de artista em face da Guerra, uma espécie de Código de Ética", nos diz Chico, a ressaltar o valor moral do poeta e a força prodigiosa de sua fé na literatura. "Mário não vive num altar, trancado numa redoma" - continua -, para em seguida exaltar a sua condição de "mestre das novas gerações", apoiado no exemplo de "A elegia de abrill", texto com que Mário incentivou a ação dos moços da

\begin{tabular}{|l|l|l|l|l|}
\hline Pensares em Revista & São Gonçalo, RJ & n. 1 & $92-116$ & jul.-dez. 2012 \\
\hline
\end{tabular}


revista Clima, de São Paulo, ele que, nas palavras de Chico, já "não acreditava mais nos homens de sua geração".

Na verdade, o Mário de Andrade que emerge da entrevista com Assis Barbosa é o homem cansado do reveses que os figurões impuseram à sua visão renovadora de intérprete da nossa gente e da nossa cultura. Frente ao peso desse legado, Chico como que amplia a ressonância das amarguras do autor, ao ouvi-lo dizer que preferia a companhia dos jovens à dos "homens sujos, que se venderam, colocando-se da banda da contra-verdade".

Daí o entusiasmo do repórter com a veemência do poeta ante a presença renovadora dos jovens. À diferença daqueles, os moços - nos termos de Mário - “estão querendo exclamar a verdade que vai chegar, mas não podem [porque] a novidade está engasgada e regouga surdamente, não por ignorância, mas porque engasgaram a mocidade". No que é secundado pela voz do próprio Chico, que se junta ao desabafo de Mário para dizer ao leitor que não são apenas os moços que regougam, "todos regougam. Não há nada a fazer senão regougar". E, cheio de ironia: "Como é bom regougar! (sic)".

Chico está na casa de Mário, na rua Lopes Chaves, bairro paulista da Barra Funda, "uma casa simples, sem luxo, mas cheia de quadros, de livros, de músicas, Lhote, Picasso, Portinari, Segall...”. O poeta lhe parece mais loquaz do que nunca, e mais remoçado, "apesar dos sinais de longa enfermidade ainda muito visíveis no rosto pálido". As revelações seguem explosivas, nos revelando um homem cada vez mais comprometido com a arte engajada.

“O artista pode pensar que não serve a ninguém, que só serve à Arte. Aí é que está o erro - adverte Mário. No fundo, ele está sendo instrumento nas mãos dos poderosos", por isso diz a Chico que não faz arte pura, "nunca fiz, para mim a arte tem de servir". E aqui recorre a um exemplo expressivo, ao revelar que, se quisesse, o romance Amar, verbo intransitivo "poderia ter saído um romance melhor (o assunto era bem bonzinho), não fosse a minha vontade deliberada de escrever brasileiro". A mesma coisa com Macunaíma, "que dizem ter saído incompreensível, devido a minha vontade de escrever um livro em todos os linguajares do Brasil”.

Aliás, para Mário - nos diz Chico - a busca dessa "maneira de escrever brasileiro", que ele passou a vida toda pesquisando, mais do que uma imposição de

\begin{tabular}{|l|l|l|l|l|}
\hline Pensares em Revista & São Gonçalo, RJ & n. 1 & $92-116$ & jul.-dez. 2012 \\
\hline
\end{tabular}


"consciência profissional", era "um problema de ordem moral", uma responsabilidade a mais que ele agregava ao ofício de escrever. No fundo, buscava duas coisas bem definidas: a primeira era lutar por uma ortografia própria, reconhecida por todos como a "nossa ortografia", fosse escrevendo cavalo com três $l l l$ ou baía sem $h$, desde que a uniformização se constituísse numa norma adotada pelos brasileiros. É que, segundo Mário, uma consequência funesta da desordem ortográfica imperante no Brasil foi ter servido de estímulo à nossa desordem mental, "impedindo a muito escritor de formar uma verdadeira consciência profissional".

Decorrente da primeira, a segunda finalidade é justamente a de demonstrar que a liberdade de pensamento só é possível "com a aquisição de uma técnica de pensar", o que significa que, na entrevista de Assis Barbosa, o leitor está diante de um Mário de Andrade cada vez mais comprometido com a arte participativa, unindo as duas pontas dessa busca por uma linguagem autêntica que nos identificasse enquanto povo. De um lado, através da convicção de que toda obra de arte nasce livremente de "uma circunstância ocasional, social ou individualista, a que o artista atribui o seu interesse"; e, de outro, através da consciência de que, no fazer poético, não é a arte que se modifica, "mas a qualidade do interesse que leva o artista a artefazer". E esse interesse é antes de mais nada o de dizer, em registro brasileiro, quem somos e de que modo pensamos e nos exprimimos.

Não é por acaso que, seis anos depois da publicação da entrevista de Mário, Chico retorna às ponderações do poeta justamente para sublinhar o peso da imaginação romanesca na evolução da prosa brasileira a partir do romantismo. E mais: ao mesmo tempo em que se dedica aos temas e autores dessa pesquisa, já está entalado até a medula na barafunda dos papéis dispersos de um Lima Barreto até então relegado ao limbo da literatura brasileira, de onde Chico o retira não apenas lhe editando e organizando a obra, em companhia de Antônio Houaiss e M. Cavalcanti Proença, mas também valorizando a sua história de rebeldia e sofrimento num livro que é, até hoje, um modelo definitivo entre as nossas biografias literárias.

Ao rastrear a evolução da prosa brasileira, Chico parte da crônica histórica romanceada $O$ aniversário de Dom Manuel em 1828, de João Manuel Pereira da Silva, mas pouco acrescenta à pauta da historiografia anterior. Teixeira e Sousa, por exemplo, não passa de um autor “destituído de valor literário", que só se distingue por representar

\begin{tabular}{|l|l|l|l|l|}
\hline Pensares em Revista & São Gonçalo, RJ & n. 1 & $92-116$ & jul.-dez. 2012 \\
\hline
\end{tabular}


o primeiro esforço continuado, de 1843 a 1859, de um escritor que pretendeu realizar uma obra de romancista", o que lhe confere um valor puramente cronológico. Joaquim Manuel de Macedo, em seus vinte e tantos volumes publicados, não foi além "de literatice, e da pior", à exceção de A moreninha (1844) cujo êxito maior, a seu ver, foi ter levado o publico a tomar conhecimento do romance, além de haver despertado em José de Alencar a vontade de ser romancista.

Se há por vezes um tom particular em seus juízos, é a intenção de destacar, no conjunto excessivamente convencional da prosa do período, a contribuição dos autores que mais enriqueceram a busca da expressão local, a mesma que recortara a pauta do bate-papo com Mário de Andrade na revista Diretrizes. É então que revemos o estilo vivo e pitoresco de Manuel Antônio de Almeida, "admirável por ter-se adiantado à sua época", abrindo o caminho depois percorrido por um Marques Rebelo e um Antônio de Alcântara Machado; a imaginação americanista de José de Alencar, responsável pela "reabilitação" do indígena, de influência decisiva em nosso meio, ainda que "carregando nas tintas"; e a revelação inédita com que Machado de Assis reconstrói a sociedade brasileira ("é como se fosse uma ilha em nossa paisagem literária”).

O que vem depois alterna o sobrevoo de ofício aos realistas menores e à geração de Coelho Neto, passando por Graça Aranha e os regionalistas, para deter-se com mais ênfase em Lima Barreto, até chegar aos modernistas e depois à prosa de 1930, com destaque para Jorge Amado, José Lins do Rego, Graciliano Ramos, ao lado de Érico Veríssimo, Cyro dos Anjos, Lúcio Cardoso, Clarice Lispector e Murilo Rubião.

Dentro das perspectivas didáticas desse esboço informativo (Chico nunca pretendeu ser crítico literário), o trabalho não deixa de ter uma contribuição, seja pelos critérios de historiografia literária, seja pela vasta bibliografia que enfeixa a matéria.

Mas é no segundo trabalho, - o notável estudo biográfico sobre A vida de Lima Barreto, de 1952, - que Chico praticamente definiu o seu modo de inserção no âmbito da literatura brasileira. Na verdade, quando recebeu, nesse mesmo ano, o Prêmio Fábio Prado, da União Brasileira de Escritores de São Paulo, o livro veio consagrar uma vocação intelectual que até então harmonizava o interesse pela reportagem literária com a intuição fecunda da crônica de gêneros e de bastidores, de tanta importância para a história das nossas letras no contexto de sua transição para o modernismo.

\begin{tabular}{|l|l|l|l|l|}
\hline Pensares em Revista & São Gonçalo, RJ & n. 1 & $92-116$ & jul.-dez. 2012 \\
\hline
\end{tabular}


O próprio Assis Barbosa se encarregaria de excluir o livro do campo das "análises profundas" que ele mesmo julgava indispensáveis para compreender uma figura tão complexa como a de Lima Barreto. Contentava-se, como escreveria depois no prefácio da primeira edição, em ser unicamente um repórter que fazia do jornalismo diário o seu ganha pão, com todas as vicissitudes que esse ofício costuma exigir dos que a ele se dedicam. Por isso mesmo, sem alardear o caminho, ajustava ao seu próprio testemunho a mobilidade do foco, o inesperado dos movimentos e a notação humana do testemunho de um Lima Barreto que acabaria moldando - também ele um repórter militante - a alma e a sensibilidade do biógrafo.

No plano reverso, por sua vez - coisa interessante na história desse livro -, o biógrafo, como talvez nenhum outro antes dele, deixaria a marca indelével do seu traço no perfil literário do escritor que nos revelava. De fato, poucas vezes antes em nossa tradição biográfica uma obra alinhou tão rente a singularidade humana do escritor biografado ao projeto narrativo de reconstruí-la por afinidade, como se a transfundisse por dentro com os elementos de sua própria ficção, rearticulando as personagens e projetando, no tempo real, a dimensão simbólica de um retrato que viria consagrar a imagem definitiva de Lima Barreto nos quadros da literatura brasileira.

E isso a tal ponto que hoje - a sessenta anos de distância - os sinais dessa afinidade tendem a reaparecer mais vivos quando pensamos, por exemplo, no Assis Barbosa poeta bissexto, que a sensibilidade melancólica de Manuel Bandeira soube captar, em 1946, mergulhado na paisagem noturna do silêncio, a meditar no abandono do mendigo, que descansava "na sombra úmida dos arranha-céus". Próximo a eles, o Mário de Andrade que o biógrafo premiado entrevistara dez anos antes, viria nos lembrar de outras "tristezas esquecidas", como a da confissão, tão cara ao Lima Barreto retratado na biografia, de que não teria publicado uma só palavra das tantas que escrevera, se tivesse sabido antes que a sua literatura não serviria de qualquer utilidade para o semelhante.

É essa linha de convergência, vinda do jornalismo para a reportagem literária, que se constitui num ponto de referência indispensável à compreensão da transitividade dos gêneros e da mutação dos estilos na passagem da Belle Époque para o modernismo, como se sabe um tema relevante no argumento do livro. Isso faz que, nos termos de seu alcance, A vida de Lima Barreto represente, no conjunto da obra de Francisco de Assis

\begin{tabular}{|l|l|l|l|l|}
\hline Pensares em Revista & São Gonçalo, RJ & n. 1 & $92-116$ & jul.-dez. 2012 \\
\hline
\end{tabular}


Barbosa, a chave de um tema cujos motivos depois se expandem por desdobramentos afins e até certo ponto complementares, se observarmos, por exemplo, que a preocupação do autor com a novela e o conto acabou repercutindo nessa descrição da trajetória de Lima Barreto, para de algum modo estender-se à investigação do relato urbano na prosa de António de Alcântara Machado (1961) e ainda na de Marques Rebelo (1968), que o saudará na Academia em 1971.

Não que essa atitude buscasse um novo ângulo para converter-se numa modalidade de crítica literária propriamente dita. Por mais que o atraíssem as virtudes do texto e o andamento virtual de sua estrutura articulada, o que de fato movia a sensibilidade de Chico eram os arcanos desse arranjo imaginado sob os ditames da vida e o arrastar-se da vontade dos homens sob as imposições do destino. Sob este aspecto, mais que construção literária, o que ele via nos livros era a face invisível da sua história e os segredos mais fundos e intransferíveis de quem os escrevia. Assim, mais que o arcabouço formal, interessavam-lhe as circunstâncias de sua origem, a paisagem da alma que os concebera, esboçada contra os vestígios do tempo, as marcas da família e da sociedade, o roteiro da formação intelectual e humana, a singularidade que tipifica o talento e o caráter.

José Lins do Rego nos dá um testemunho valioso dessa técnica utilizada por Chico, ao nos dizer que em seu "estilo suave e livre, as notas mais agudas se fixam sem agressividade, como num álbum de fotografias", em que as figuras tratadas "entram com passos de lã, [...] devagar, como se [tudo] fosse passado em máquina de Cosmorama". É a melhor imagem sobre os seus Retratos de família, livro que Chico publica em 1956 pela José Olympio, no qual descreve a vivência familiar de escritores, intelectuais, políticos e homens de ciência a partir do relato dos que conviveram com eles.

A obra, na melhor expressão da índole jornalística de Assis Barbosa, é o registro reminiscente de contextos humanos e afetivos em busca de fatos e curiosidades que de outra forma permaneceriam inacessíveis ao leitor comum. Graças ao talento do repórter, retrocedemos aos tempos escolares de alguém como Lúcia Miguel-Pereira, que o texto retrata ora como a menina apanhada no colégio pelo pai ilustre, o higienista Miguel Pereira, ora como sua acompanhante a uma tarde de corridas no antigo Jóquei Clube de São Francisco Xavier, onde a garota surpreende o honorável pai - tenaz amante do turfe

\begin{tabular}{|l|l|l|l|l|}
\hline Pensares em Revista & São Gonçalo, RJ & n. 1 & $92-116$ & jul.-dez. 2012 \\
\hline
\end{tabular}


- arrancando o binóculo das mãos de um apostador vizinho para "ver de mais perto" o desfecho da carreira.

E que dizer do episódio em que o futuro conselheiro Rui Barbosa, em companhia de Rodolfo Dantas enrolado num lençol, aparece fardado de chefe de polícia nos festejos de uma noite de entrudo? Como, ainda, imaginar o erudito doutor Sílvio Romero despejando um balde d'água fria sobre o casal de namorados que se divertia às gargalhadas sob a janela de seu gabinete de trabalho?

Cenas como estas - que dão ao livro uma singularidade de campanha alegre juntam-se, no curso da narrativa, a revelações pouco convencionais, se pensarmos no procedimento normalmente equilibrado de certas reputações consolidadas de quem jamais suporíamos o menor despropósito. Como entender, por exemplo, o exibicionismo irrefreável de Joaquim Nabuco, que, certa noite, num jantar de gala que oferecia em Roma, resolveu transformar o salão do hotel num imenso lago por cujas águas deslizava uma gôndola iluminada - ele mesmo, Nabuco, que pouco antes, em Londres, não hesitara em mandar construir uma enorme montanha de gelo, fazendo-a decorar com rosas vindas especialmente de Nice?

É verdade que outros depoimentos nos tocam pela extensão amarga de suas consequências, como no caso do relato em que João Alphonsus de Guimaraens recorda a longa e penosa viagem que, ainda criança, fez em 1906 acompanhando o pai, o poeta Alphonsus de Guimaraens, ao lado da mãe e quatro irmãos pequenos - entre Conceição do Serro e Mariana, distrito em que o grande simbolista assumiria o cargo de juiz municipal. Foram “doze dias a cavalo, tomando sol e poeira pelos caminhos", os irmãos acomodados "em caixotes pendurados na cangalha de um burro velho, que um preto puxava pelo cabresto".

Não é difícil imaginar os padecimentos que marcaram para sempre o coração daquele menino, então com apenas cinco anos, aflito ainda agora ao se lembrar que dos cantos daqueles caixotes "partiam varas para suster o toldo de pano grosso e grosseiro, proteção contra os raios diretos do céu escampo - nos diz ele - mas não contra o calor sertanejo que, com o balanço dos passos do animal, dava um sono invencível [...] naquela paisagem lentíssima de matos, roças, várzeas, raras moradas de porta e janela, em distâncias que a vagareza tornava astronômicas".

\begin{tabular}{|l|l|l|l|l|}
\hline Pensares em Revista & São Gonçalo, RJ & n. 1 & $92-116$ & jul.-dez. 2012 \\
\hline
\end{tabular}


Mas há outros momentos que alternam cenas de alegria e ternura, dando ao livro de Chico uma dimensão particular de jornalismo de bastidores duplicado de crônica de família e repertório de gerações, substratos inéditos de que Gilberto Freyre foi o primeiro a distinguir "os traços largos da inteligência e do coração". Uma de suas expressões mais vivas está, por exemplo, nas três imagens de Mário de Andrade, que Chico registra ao longo de uma conversa com o irmão mais velho do poeta, Carlos de Morais Andrade, a quem Mário confiara uma carta-testamento um ano antes de morrer.

Na primeira, uma reação intempestiva: depois de ler a pedido de Mário alguns de seus poemas "futuristas, Carlos - que "não compreendia a arte moderna" - vira-se para o poeta: "Não entendo nada, meu irmão". E Mário, carregando nos erres: "Você não entende porque é bu-r-r-ro..." ( $\mathrm{sic}$ ).

$\mathrm{Na}$ segunda, Mário aparece em cena caseira, narrada ("gloriosamente, como um general relatando uma vitória") por dona Sebastiana, cozinheira da família por mais de trinta anos e grande companheira do poeta. "Mário, certa vez, chamou-me para fazer um peru com castanhas; escreveu a receita, muito bem explicadinha, e falou cheio de recomendações: - 'Quero o peru muito bem feito. Olhe que é para meus amigos do Rio'. Pois eu fiz o peru à minha moda - ela emenda - e saiu melhor que a receita".

A terceira imagem nos põe diante da grandeza intelectual e humana do autor da Lira paulistana, ao recomendar ao irmão Carlos, em sua declaração de última vontade, que não vendesse os objetos e obras de arte que veio comprando e juntando pela vida afora. "Nunca colecionei pra mim, - explica o poeta -, mas imaginando me constituir apenas salvaguarda de obras, valores e livros que pertencem ao público, ao meu país, ao pouco que eu gastei e me gastou".

Haveria outros flagrantes a destacar nos depoimentos colhidos por Chico nestes Retratos de família - o de Roquette Pinto chefiando uma tribo em seu sitio da Barra da Tijuca, ele próprio transformado no cacique Iuraçu, a comandar os filhos e familiares, também ajaezados e batizados à feição indígena, sempre prontos para saudar em tupi o visitante que chegava, ao toque solene de um tirado alto de tuba; ou ainda o dos filhos de Artur Azevedo, que o chamavam de Passarinho, "subindo-lhe pela imensa barriga para lhe beijar as bochechas", entre as risadas do pai alegre, que se divertia: "Passarinho, um elefante como eu!" - haveria ainda muito a dizer, mas é tempo de seguir adiante. Principalmente para deixar assinalado que o interesse pela literatura, a

\begin{tabular}{|l|l|l|l|l|}
\hline Pensares em Revista & São Gonçalo, RJ & n. 1 & $92-116$ & jul.-dez. 2012 \\
\hline
\end{tabular}


crítica e a história literária serão os temas predominantes nos livros que o autor produzirá entre 1957 e 1968, sem contar a obra póstuma de 2001, que tem por tema a correspondência entre António de Alcântara Machado e Alceu de Amoroso Lima, editada pela Academia Brasileira de Letras.

É certo que, no breve estudo sobre Machado de Assis, que publicou em 1957, Chico fará questão de esclarecer que não teve qualquer pretensão de apresentar uma "contribuição original", senão a de fazer conhecer aos mais jovens como foi a vida do autor do Quincas Borba. O que ali buscava era narrar a história de uma vida simples, "toda ela dedicada ao ofício de escrever", e marcada pela honestidade e o amor ao trabalho por parte de alguém que, como Machado, "sempre acreditou na literatura brasileira".

Como se vê, ainda aqui o amor às letras reflui para o desenho histórico das circunstâncias que envolvem o escritor e a evolução de sua vida literária, chaves de que o repórter se vale para enriquecer, na trajetória de Machado, alguns episódios e revelações do mais vivo interesse. Não que rigorosamente seja o primeiro a desvendálos, mas pela originalidade do recorte, quase sempre os recuperando pelo lado menos conhecido de suas particularidades.

Entre o cotidiano de menino pobre que vendia balas e doces pelas ruas, depois da fase de moleque solto pelas vielas do Morro do Livramento, logo após a morte de sua mãe, o leitor acompanhará a transformação do "menino diabo" convertendo-se aos poucos no grande homem de talento e cultura que foi Machado.

É assim, por exemplo, que ficamos conhecendo Mme. Gallot, dona de uma padaria próxima ao colégio em que ele estudava e responsável por seus primeiros diálogos em francês, língua em que o menino se exercitava, com ela e o forneiro da casa, tirando lições que foram depois decisivas para a sua ascensão nas oficinas da Tipografia Nacional, aonde chegaria em 1856 levado pelo amigo Paula Brito, com um salário de 1 pataca por dia. Aqui, as relações se expandem e muitas vezes surpreendem, ao nos mostrarem a amizade com Casimiro de Abreu, a quem o jovem Machado acompanha no vezo romântico da poesia da época. Mas vem o tempo dos artigos democráticos na revista $O$ espelho, da convivência amiga com Manuel Antônio de Almeida, que o aproxima de Francisco Otaviano, Quintino Bocaiuva e José de Alencar,

\begin{tabular}{|l|l|l|l|l|}
\hline Pensares em Revista & São Gonçalo, RJ & n. 1 & 92-116 & jul.-dez. 2012 \\
\hline
\end{tabular}


inclusive o levando à casa do escritor francês Charles Ribeyrolles, à época exilado no Brasil.

A partir daí entramos na face mais conhecida da trajetória de Machado: as lutas como redator de $O$ liberal, aos 21 anos de idade, ao lado de Quintino Bocaiuva e Saldanha Marinho; a nomeação para diretor do Diário Oficial e o casamento com Carolina Augusta Xavier de Novais.; as primeiras publicações pela B.L. Garnier, a ida para Secretaria da Agricultura e a ruptura definitiva com o romantismo, a que se segue a fase dos romances maduros, a presidência da Academia Brasileira Letras, o golpe de sua demissão do Ministério da Agricultura por ato do presidente Prudente de Morais, os percalços com a epilepsia, o retorno ao ministério em 1907, a perda da esposa, a nomeação para diretor geral de contabilidade e afinal a morte em 29 de setembro de 1908, cercado pelos amigos Euclides da Cunha, Mário de Alencar, José Veríssimo, Raimundo Correia, Graça Aranha, Rodrigo Otávio e Coelho Neto.

É dentro dessa angulação entre a obra escrita e o desenho histórico de suas origens que o repórter Chico Barbosa defenderá, no ano seguinte, uma atitude ostensivamente militante frente à literatura, para ele uma atividade impossível de separar da política, a menos que consideremos "escritores e políticos uns rematados imbecis". É que - para ele - ao publicar uma obra, o escritor reflete sempre "um estado de espírito, individual ou coletivo, que atuará sobre todo o complexo da organização social e político-social do país".

O dado novo do argumento é que - levado em grande parte pela influencia intelectual sobretudo de Mário de Andrade e Alcântara Machado - Chico vai situar o foco dessa atitude no ponto de virada do movimento modernista, a partir do qual - a seu ver - se definiu a renovação de mentalidade desarticuladora do autodidatismo predominante no Brasil anterior aos anos de 1930. Só depois do modernismo - nos dirá ele - é que os nossos escritores romperiam com o convencionalismo e o pitoresco que "recheavam a sintaxe lusa com o vocabulário caipira", sujeitando-os a um colonialismo estilístico que os fazia escrever "como se fossem escritores portugueses e não brasileiros".

Mesmo reconhecendo, e sublinhando, as exceções de Manuel Antônio de Almeida, José de Alencar e Lima Barreto, com os quais se consolidava "uma outra maneira de sentir o Brasil", Chico retorna em seu novo livro ao contexto do nosso

\begin{tabular}{|l|l|l|l|l|}
\hline Pensares em Revista & São Gonçalo, RJ & n. 1 & $92-116$ & jul.-dez. 2012 \\
\hline
\end{tabular}


romantismo, que considerava fechado às inovações do método e da pesquisa, por vezes diretamente contestada pela férula dos "mestres" portugueses, como no caso dos quinaus de Antônio Feliciano de Castilho, que, em 1847, andou por aqui feito um "autêntico sensor português", aplaudido inclusive pelo Imperador.

Mas não é apenas por esse confronto entre nativistas e pés de chumbo que os seus Achados do vento se pautam. A implicância contra o "respeito quase religioso" ao vernáculo intocável, que vigora entre nós para muito além do "Sete de Setembro", reveste-se, no livro, de registros bem mais pontuais, sem - é verdade - cair no jacobinismo fora de propósito. Passando pela pesquisa sistemática de Mário de Andrade, que, mesmo investigando a fala típica da nossa gente, esteve longe de propor a criação de "uma língua brasileira", Chico mergulha no sentido inovador dos experimentos de Oswald de Andrade e Alcântara Machado (como também nos de Mário) em sua luta pelo direito de enriquecer a língua "em nossa terra emancipada e livre", contra o convencionalismo dos medalhões e da "inteligência empalhada".

É por aí que Chico se detém na infância penosa de um Graciliano Ramos dilacerado pela rudeza do chão agreste, ignorado pela própria mãe ("vivia pelos cantos levando cascudos e só se sentia contente quando fugia para o fundo do quintal e lá ficava a amassar barro com os pés de uns enormes tamancos”), e, sem que o soubesse, abrindo-se, nesse martírio precoce, para a nebulosa inaugural de uma obra reveladora da crua realidade do sertão, que ele vai transfundir com uma linguagem que brota da própria terra, tartamelada na boca de personagens brutalizados, cujos sentimentos primitivos jamais couberam nos "requintes do Brasil civilizado" em que pululavam os acadêmicos do novo século.

É para estes, aliás, que Chico volta os seus olhos ao dialogar com Manuel Bandeira sobre os seus mestres no Colégio Pedro II, com destaque para Sílvio Romero, o grande responsável pela iniciação do poeta de Libertinagem na arte de desvendar os versos dos velhos clássicos portugueses enquanto "matéria viva", e não mais como "antigualha didática". Isto para não referir o capítulo sobre Lima Barreto e sua "literatura de compromisso", em que Chico nos mostra jovem autor da Bruzundanga descobrindo o racionalidade do Discurso do método, de René Descartes, cuja influência se revelou tão decisiva em seu espírito, que o acabou transformando numa espécie de

\begin{tabular}{|l|l|l|l|l|}
\hline Pensares em Revista & São Gonçalo, RJ & n. 1 & $92-116$ & jul.-dez. 2012 \\
\hline
\end{tabular}


pioneiro da dúvida metódica enquanto ferramenta para traduzir como farsa as disparidades que infestavam as letras e a cultura de seu tempo.

E há também - como deixar de mencionar? - o pequeno estudo sobre a trajetória intelectual de José de Alencar, entre a advocacia, a política e a vocação letrada que se debatia na imprensa e nos livros para fazer valer a sua identificação com a terra; a mesma que o levaria, magoado, a lamentar, em carta a Francisco Otaviano, que o Diário do Rio de Janeiro, dirigido por este último, o preterira em favor do português Mendes Leal, que o jornal dava como o verdadeiro criador do romance americano, desconsiderando a pesquisa ficcional e histórica que ele próprio, Alencar, e não outro, fora o primeiro a buscar nos grotões mais íntimos da paisagem brasileira.

$\mathrm{Na}$ verdade, será preciso ir aos percalços de Domingos Caldas Barbosa menosprezado por um Bocage invejoso do sucesso de suas modinhas, que davam "a nota chic das festas da Corte", para confirmar o ânimo localista que agora impulsionava a decisão do repórter em fazer valer, de uma perspectiva participativa e mesmo militante, o alcance da virada modernista em busca das nossas raízes autênticas. Como lembra o próprio Chico no capítulo sobre o poeta violeiro, mesmo chamado em toda parte, "nos salões das casas fidalgas em Lisboa e Sintra, Benfica ou Bemposta, até mesmo nas quintas reais de Belém, Caxias e Queluz", mesmo nomeado capelão da Casa da Suplicação, Caldas Barbosa "jamais deixou de lado a viola e as modinhas que o celebrizaram".

É nessa tensão entre a reportagem e a biografia, entre a cultura e a historiografia literária que se definirá a contribuição de Assis Barbosa à vida intelectual brasileira. Com esse perfil é que ele desenvolverá, na outra ponta de seu projeto, ensaios históricos e biográficos; estudos introdutórios e bibliográficos acerca da vida de intelectuais, políticos e historiadores; também com ele, mergulhará no estudo das influências francesas no Brasil, das ciências e as artes à colonização, da política aos costumes e à própria linguagem. Isso tudo sem mencionar a contribuição institucional que o levou, a partir do ingresso na Academia Brasileira de Letras, em 1971, a assessorar a pesquisa de fontes e a sistematização de acervos bibliográficos, colaborando na organização de enciclopédias, de bibliotecas e outros organismos culturais do país.

Mas, para nos restringir apenas ao espírito destas notas, interessadas sobretudo nas relações entre o jornalista e o repórter de cultura dobrado de crítico e cronista literário,

\begin{tabular}{|l|l|l|l|l|}
\hline Pensares em Revista & São Gonçalo, RJ & n. 1 & $92-116$ & jul.-dez. 2012 \\
\hline
\end{tabular}


para só ficarmos neste aspecto, acrescentemos - à maneira de conclusão - os dois últimos movimentos que enfeixam, na trajetória do nosso autor, a simetria entre a imaginação estética de ensaísta e a notação documental moldada pela precisão do relatoflagrante.

No caso do primeiro, serve de exemplo a "Nota sobre António de Alcântara Machado", publicada como introdução às Novelas paulistanas e centrada na leitura abrangente não apenas da prosa inovadora do criador do Gaetaninho, como também de suas relações com Mário, Oswald, Paulo Prado e outros representantes do modernismo, que Chico revisita seja no plano do ideário estético do movimento, seja no de sua dimensão interna, elucidando os bastidores do projeto literário da Semana e enriquecendo-o de notas esclarecedoras sobre a obra, a personalidade e a convivência pessoal muitas vezes tensa entre alguns dos então chamados futuristas. Se é verdade, como atrás afirmamos, que os critérios de Chico se deixam levar às vezes por algum excesso em favor do nacionalismo literário, o fato é que, ao ajustar, por exemplo, o tom "berrantemente modernista" do Retrato do Brasil às teses do Manifesto regionalista, de Gilberto Freyre - sem os quais, a seu ver, seria impossível compreender o Brasil - essa introdução às novelas de Alcântara Machado veio aclarar a fisionomia das relações literárias entre os dois autores.

A repulsa ao "estilo asnático"; a insinceridade de Oswald de Andrade em sua adesão ao comunismo; a frieza de Mário de Andrade ao recepcionar em São Paulo o comunista Astrojildo Pereira, tão festejado por Alcântara, um "antifascista da primeira hora" que trazia no peito a certeza de que nenhuma força humana seria capaz de deter o trabalhador brasileiro quando este lograsse alcançar um dia, por si mesmo, a organização de suas próprias forças, - tudo isso e o sobrevoo pontual sobre a integração da personagem do imigrante no complexo social paulista (Tito Batini, J. Carneiro, para não falar de Oswald de Andrade e dos insights do narrador de Mana Maria, que Alcântara Machado deixou inacabado), abre caminho para o diálogo que será depois retomado em 2001 com a publicação pela Academia Brasileira de Letras do livro póstumo Intelectuais na encruzilhada, onde reaquece o debate sobre o modernismo e a crônica de suas contradições, agora filtradas na correspondência de Alcântara Machado e Alceu Amoroso Lima entre 1927 e 1933.

\begin{tabular}{|l|l|l|l|l|}
\hline Pensares em Revista & São Gonçalo, RJ & n. 1 & $92-116$ & jul.-dez. 2012 \\
\hline
\end{tabular}


É no segundo movimento dessa etapa, entretanto, que Chico vai encontrar o verdadeiro espelho de seu ecletismo, ao se debruçar, no ensaio "Um dom Quixote das letras", sobre a obra e a trajetória do crítico e historiador literário José Brito Broca, seu conterrâneo de Guaratinguetá. Não que um servisse de modelo às incursões literárias do outro, espíritos incompatíveis que eram. Mas sobretudo em razão das afinidades que os aproximavam nesse empenho pela reconstituição do passado cultural, a que se acomoda - em relação ao método e aos objetivos de ambos - a conhecida imagem do "escritor partido aos pedaços", utilizada por Brito Broca em entrevista a Renard Peres.

A rigor aplicam-se ao próprio Chico os termos com que ele definiu o perfil de Brito Broca, quando afirmou que este "não se considerava um crítico realizado ou um historiador de ideias, mas um simples leitor ou anotador de livros", valendo-se, aliás, de uma expressão do próprio amigo. O fato é que, no caso de Broca, prevaleceu sempre um interesse mais afinado com a arte literária e a história da literatura vistas de um ângulo mais próximo do cânone, muitas vezes com o olhar imantado pela magia dos temas ou a sutileza da composição, ainda que de uma perspectiva livre mais afeita ao comentário que à logica da análise, ao escrito antes informativo que propriamente formador, desvinculado das imposições conceituais do método, como seria de praxe no exercício regular da crítica.

Como entretanto não ver convergência no horror de ambos pela literatice, no sentimento comum de ver na obra literária "o território sagrado em que a vida e a humanidade se exprimem"? Se é verdade que ao isolamento de Broca jamais correspondeu o percurso agitado do repórter Chico Barbosa, o fato é que para ambos o trabalho do escritor só se justificava na pesquisa intensa, fosse na criação artística como na investigação literária.

O interessante no ensaio de Chico são as revelações de simetrias a partir de temas que lhe eram caros, como na passagem em que Brito Broca, mesmo adepto do "beletrismo ortodoxo", soube demonstrar com lucidez que, ao contrário das suposições de Astrogildo Pereira, por exemplo, a arte de Machado de Assis jamais esteve desvinculada da política, conforme o revelam tanto a análise da psicologia de Cotrim no romance das Memórias póstumas de Brás Cubas, quanto o fino recorte do pensamento escravocrata a partir da mesquinhez do Barão de Santa Pia, no Memorial de Aires. E mais: essa defesa de Machado por Brito Broca, nos diz Chico que "é em última

\begin{tabular}{|l|l|l|l|l|}
\hline Pensares em Revista & São Gonçalo, RJ & n. 1 & $92-116$ & jul.-dez. 2012 \\
\hline
\end{tabular}


instância a defesa do próprio Broca”, um escritor que, por não ser um militante social, nem por isso mostrou-se indiferente à nossa realidade e às obras que a refletiam, a ponto de muitas vezes ter perdido as estribeiras nas "rumorosas discussões literárias" que costumava travar com o amigo Otto Maria Carpeaux na cantina do Correio da Manhã durante os intervalos do jantar.

Mas o lado que mais o aproxima de Brito Broca aparece nos flagrantes de uma cena comum à trajetória de ambos, animada "pelo ardor e a efusão lírica" com que enveredavam pelos arredores da cidade atrás de vestígios que se perderam. Brito Broca, como Assis Barbosa, foi também a seu modo um repórter dos homens e das coisas de outros tempos, e é comovente o modo como Chico o recorda a percorrer os bairros do Rio de Janeiro, “deixando-se ficar a sós numa praça distante, ou num café modesto de arrabalde, - como ele próprio na longínqua rua Lopes Chaves de outrora, à espera de Mário de Andrade, - excursionando pelas imediações de nossos morros e em recantos típicos, à busca ansiosa dessa coisa vaga, fugidia, terrivelmente abstrata que se costuma chamar o espírito da cidade".

Se foi assim que Chico reconstruiu e pôs de pé a obra e a personalidade intelectual de Lima Barreto, do mesmo modo o amigo Brito Broca extraiu das ruas e sobretudo dos livros os sinais da "preciosa chave" com que os escritores do tempo de Machado de Assis e de Lima Barreto, do romantismo e da Belle Époque, da Academia e da transição do fim do século definiram um momento particular das nossas letras. Em Chico, como em Brito Broca, essa evocação resultou num veio memorialístico tão decisivo à evolução do gênero, entre nós, que os transformou num contraponto imprescindível à compreensão da modernidade em nossas letras.

\section{Referências bibliográficas:}

Textos de Francisco de Assis Barbosa citados neste ensaio:

De Retratos de família [2a. ed., revista e acrescida de três novos capítulos. Rio de Janeiro: José Olympio (1968)]: "Miguel Pereira visto por Lúcia Miguel-Pereira"; "Rui Barbosa visto pela esposa d. Maria Augusta e sua filha Maria Adélia" e "Sílvio Romero visto por Edgar e Nelson Romero"; "Joaquim Nabuco visto por Carolina Nabuco"; "Alphonsus de Guimaraens visto por João Alphonsus de Guimaraens"; "Mário de Andrade visto por Carlos de Morais Andrade".

Machado de Assis em miniatura [São Paulo: Editora Melhoramentos (1957)].

\begin{tabular}{|l|l|l|l|l|}
\hline Pensares em Revista & São Gonçalo, RJ & n. 1 & $92-116$ & jul.-dez. 2012 \\
\hline
\end{tabular}


De Achados do vento [Rio de Janeiro: MEC/INL (1958]: "Nacionalismo e política"; "Graciliano Ramos, aos cinquenta anos"; "Manuel Bandeira estudante do Colégio Pedro II"; "Lima Barreto precursor do romance social"; "José de Alencar, cronista do primeiro encilhamento"; "Domingos Caldas Barbosa, o poeta da viradeira".

"Nota sobre António de Alcântara Machado" in António de Alcântara Machado. Novelas paulistanas. Rio de Janeiro: José Olympio (1961), especialmente pp. 13-48.

A referência ao Correio da Manhã, do Rio de Janeiro, é de 15 de setembro de 1956.

Artigo recebido em 21 de agosto de 2012.

Artigo aprovado em 15 de setembro de 2012.

\section{Sobre o autor:}

Graduado em Letras Vernáculas pela Universidade de São Paulo (1970) e em Ciências Jurídicas pela Pontifícia Universidade Católica de São Paulo (1967). Mestre (1975) e Doutor (1980) em Letras pela Universidade de São Paulo. Pós-doutor pela Fondazzione Gianjaccomo Feltrinelli (1986). Atualmente é professor titular da Universidade Estadual de Campinas (UNICAMP). Estuda, principalmente, os seguintes temas: Prémodernismo, Modernismo, Crítica literária, História Literária. Organizou recentemente a obra Lima Barreto: uma autobiografia literária (Editora 34, 2012). Foi também organizador da coletânea de ensaios Na rua (Editora IMS, 2009). Publicou, individualmente, Itinerários de uma falsa vanguarda (Editora 34); Trincheira, palco e letras (Cosac Naify, 2004) e Lima Barreto: o crítico e a crise (Martins Fontes, 1989), dentre outros livros.

\begin{tabular}{|l|l|l|l|l|}
\hline Pensares em Revista & São Gonçalo, RJ & n. 1 & 92-116 & jul.-dez. 2012 \\
\hline
\end{tabular}

